\title{
Impact Of Secondary School Geography Content In Mitigating Climate Change In Uganda
}

\author{
Mwangu Alex Ronald ${ }^{*}$, Kagoda Alice Merab¹, \\ Mugimu Christopher Byalusaago ${ }^{1}$ \\ Faculty of Education, Kabale University \\ ${ }^{1}$ School of Education, Makerere University
}

\begin{abstract}
Climate change is a key concern to the local and global community. Because of its transformative nature, education both formal and informal has been identified as the vehicle for mitigating climate change. Many education systems however have been found lacking content necessary to produce learners that will lead efforts in mitigating climate change. Content is a very important element of the education process. It forms the basis for teaching and learning. Geography as an interdisciplinary subject is most suitable to teach learners about climate change. This study investigates the contribution of secondary school geography content in mitigating climate change in Uganda. Through questionnaires and interviews from geography teachers, this study reveal that content about climate change in the secondary school geography curriculum in Uganda is not explicit. The climate change content lies at the background of other topics and requires expertise of the teachers to retrieve it. Therefore teaching about climate change depends on interest and capacity of individual teachers.
\end{abstract}

Keywords: Curriculum content, geography education, climate change, secondary school.

\section{Introduction}

Climate change is one of the most important concerns in the global development agenda (UN, 2010). Climate change impacts on every aspect of human beings in the present and the future. The aspects of human life affected by climate change include the basic needs namely water, food, health and shelter. Changes in climate threaten these needs by the increased temperatures, sea level rise, changes in precipitation and more frequent or intense extreme events. As a result of climate change, formerly cold areas are becoming hotter, floods are becoming severe and covering areas that were not known to experience flooding before, seasonal changes are experienced by local communities and consequently reducing the farming activities. In addition, the spread of diseases and pests that affect crops, animals and human beings has increased. This confirms that climate change is affecting the sustenance of life as well as development.

Climate change is caused by natural and anthropogenic activities. Countries in Sub-Saharan Africa are most affected due to their reliance on climate sensitive natural resources and rain fed agriculture, tourism, trade, food security, water resources, energy, transport, wild life and forestry. Production of rain fed agriculture in sub Saharan Africa is highly vulnerable to the impacts of climate change due to the changes in rainfall patterns and increasing temperatures (Viljren, 2013).

Scientists confirm that climate change is happening and its impacts are set to increase. Much as climate change is a serious problem, little progress has been made in mitigating it. It has taken a while for climate change to be prioritized "partly because it has been communicated as a scientific problem which was originally complex, confusing and at times contested scientific information which resulted to a slow public and political awareness (Nancy, 2012 p.23). As a result communities have done very little to prevent the outcomes of climate change (Rakib, Akter and Majumder 2016). This implies that awareness of the population is critical in managing climate change. Several studies (Ocheing and Koske, 2013; Chang, 2013; Skalik, 2015) have emphasized the importance of awareness of citizens in mitigating climate change but at the same time noted that awareness of climate change was low among all segments of society. Raising awareness on climate change is important for accepting and addressing important behavioural norms by either reducing or improving to cause the desired change (Chang, 2013). However, the approaches and content used in constructing awareness about such behavioural norms may not as such be effective.

Chang (2013) observes that there have been many public events and campaigns through mass media aimed at raising awareness about climate change in Singapore but the campaign only galvanized a small portion of the population to change their behavior in order to mitigate climate change. It is widely accepted that education and schools in particular possess the best opportunities of creating awareness for mitigating climate change. Schools provide a favourable environment that promotes positive attitudes and behaviours towards 
climate change. Formal lessons can also help reinforce the concept climate change which in turn influences students' knowledge, skills, attitudes and behavior towards climate change. Geography education contributes a lot in this aspect. Geography is an interdisciplinary subject and its practical nature helps learners to understand change, conflict and key issues which impact their lives presently and which will affect their future (Ofsted, 2008). Indeed, Ofsted (2008) describe the importance of geography education:

"It is important that the citizens of tomorrow understand the management of risk, appreciate diversity, are aware of environmental issue, promote sustainability and respect human rights and social inclusion. If the aspiration of schools is to create pupils who are active and wellrounded citizens, there is no more relevant subject than geography" Ofsted, (2008 p.6-7).

Geography as a discipline is pivotal in the school curriculum because it is both forward looking and progressive, and at the same time seeks to conserve tradition (Lambert and Morgan, 2010). Therefore geography bridges the gap between the past, the present and the future. Geography education is indispensable to the development of responsible and active citizens in the present and future world (IGU, 1992). It provides opportunities for reflection and self-assessment of personal and society experiences and helps the learners to make informed decision. Geography education aims to produce reflective and critical thinkers. Graduates with such abilities are critical in mitigating climate change and its associated challenges. For geography education to produce citizens with such qualities, its content must be appropriate to bring about the desired outcome.

\section{Curriculum content}

Any educational activity and process to be successful depends on content or subject matter to be imparted by the teacher to the learners. Content is the most important aspect in the teaching and learning process. Gosse and Hansel (2014) emphasize the importance of content in the curriculum when they compare it to oxygen in human beings. Teachers come to class to deliver content which develops knowledge planned in the lesson. Learners pick the content from class and make reflections, develop innovations and find ways of applying in their daily lives. Content is all that schools have and offer.

Gosse and Hansel (2014)urgethat teaching is always about something, and that something has to be specified before any decision can be made. The "something" is in reality the content. The content is a necessary condition for improving schools, closing the achievement gap, engaging parents and preparing teachers. Therefore when educators take the content for granted, they lose the opportunities to coordinate and collaborate the learning experiences (Gosse and Hansel, 2014).

Eisner and Valance (1974) argue that for teachers to develop writing, thinking or solve problems, they must have something to write about, to think about or some real problem to solve. They conclude that these important learnings require content. Eisner (1990 p.524) emphasizes the importance of content in teaching by observing that "no matter how well something is taught, if it is not worth teaching, it is not worth teaching well". Curriculum theories address questions about which knowledge is most important or of worth of inclusion (NAEYC, 1990). Children have an intrinsic need to exercise their mental abilities and to make sense of their experiences but teachers need to identify content that intrigues children and arouses in them the need to figure something out (NAEYC, 1990). Teachers play an important role in choosing content to create awareness and foster interest in children by planning the environment and introducing new and stimulating objects, people and experience. While content is critical for achieving the desired objectives of various curricula, many curricula globally have inadequate content to realize the intentions of instruction(Stern and Stern, 2011). This limits the achievements of goals and objectives of teaching and learning.

\section{Climate change content in the curriculum}

A number of studies have investigated the formal education system and found out that climate change content does not appear in the curricula of various countriesi.e. Kenya, Seychelles, Nepal, Swaziland (Ndiritu et al, 2016; Ocheing and Koske, 2013; Bajracharya, 2012; Dlamini and Shongwe, 2015). In some countries environmental themes that provide an opportunity to teach and learn about climate change exist but climate change per se is not explicit (Chineka and Chabikwa, 2015; Alberto, 2015, Taba et al, 2015). For example, in Tanzania, climate change content has always appeared in the school curriculum at primary and secondary school level although it is not explicitly stated (Hanai and Ndibuni, 2015). However, the existence of climate change content in the curriculum is not a magic bullet because there are other challenges that can hinder its teaching. For example, in South Africa, climate change is included in the curriculum but many teachers have no capacity to teach it (Togo et al, 2015). In Swaziland, the government issued guidelines to integrate environment issues which may incorporate climate change but some schools have paid scant regard to it and the teachers are not conversant and don't link topics to climate change (Dlamini and Shongwe, 2015).

Muchanga and Nakazwe (2015) observe that climate change is included in curriculum of Zambia as a separate topic but does not provide any definition of the concept and the curriculum only outlines globalized causes, effects, mitigation measures and the impact of climate change in a very simplest way. The lack of a 
contextualized content in climate change coverage would do more harm to the learners because they wouldn't appreciate the essence of learning about it (UNESCO, 2012; Muchanga and Nakazwe, 2015).

Content is found in learning resources i.e. the syllabus, text books, video, CD rom, photographs, etc. These learning resources i.e. syllabus, textbooks are trusted by teachers as authoritative and objective sources of information (UNESCO, 2016). In most classrooms, textbooks determine what and how teachers teach (Kira and Komba, 2015). In some contexts, textbooks are the first and sometimes the only books that a young person may read (Lässig and Pohl, 2009). But in many parts of Africa, textbooks are either not available or not adequate and worse still outdated (UNESCO, 2016; Kira \&Komba, 2015). Some geography text books have unclear concepts regarding the issues climate change and other textbooks refute scientific findings on climate change (Kira and Komba, 2015; UNESCO,2016). In Angola and Democratic Republic of Congo (DRC) some text books with climate change content are available but inadequate (Alberto, 2015; Taba et al, 2015). In South Africa, climate change related resources which are tailor made to suit the curriculum are available and produced in series i.e. learner's textbooks, learner's workbooks and copyright free materials, however teachers lack skills and expertise to use the materials (Togo et al, 2015). These limit the possibility of the education system addressing climate change effectively to learners.

\section{Context of the study}

Climate change is a reality in Uganda and it is affecting all aspects of socio-economic development. Uganda ranks 159 out of 178 countries in the ND index(2013) which is worse than 2010 (rank 156). By implication Uganda is getting more vulnerable to climate change effects. Further, Uganda ranks $15^{\text {th }}$ on vulnerability and $147^{\text {th }}$ on readiness implying that it is very vulnerable to, yet very unready to combat climate change impacts. Uganda is experiencing the signs and effects of climate change as manifested by rainfall patterns that are low and poorly distributed, prolonged drought, emergency of diseases like Malaria in areas that were previously mosquito free, loss of soil fertility emanating from heavy over run, frequent floods, higher temperatures which provide fertile impetus for pests and diseases (GoU, 2013). Climate change is to blame for loss of human life and animals; and food insecurity.Uganda's Vision 2040 concedes that "one of the challenges to the country's development is the weak management of environment and climate change" (GoU, 2013 p.5). Education lies at the centre of reducing vulnerability and at the same time increasing readiness because any effective intervention needs individuals and societies that are aware of the various aspects of climate change.

\section{Statement of the Problem}

Climate change is one of the most serious societal problems facing humanity locally and globally. According to the National Development Plan NDP II (2015/2016- 2019/2020), climate change is not only a challenge to the population but also one of the greatest challenges impeding growth and the country's transition from a low income country to a mid-income country. Uganda Vision, 2040 states that there is still poor understanding of climate change and climate variability and hence inadequate adaptation and mitigation measures currently in place (GoU, 2013). Education is among the decisive trajectories for resilience, safe adaptation and mitigation of climate change. Geography as an interdisciplinary subject possesses the best opportunity to deliver content about climate change. Geography as a subject that teaches human-environment relationship is supposed to address the serious society problem by equipping the learners with the relevant knowledge and developing their skills to avoid and address bad practices that cause and promote climate change. Nevertheless, the environment continues to be degraded and people continuously suffer from the consequences of climate change i.e. the severe floods and increasing drought and desertification. Every time extreme climate change events struck, the students and community members seem to be taken by surprise and unawares and therefore unprepared resulting into grave damage and consequences. The secondary school students seem not to have the relevant knowledge, the practical skills and appropriate attitudes to mitigate climate change. This is likely to increase the scale and magnitude of climate change. This raises one to question the kind of content geography teachers are relaying to students in efforts of mitigating climate change.

\section{Purpose of the study}

The purpose of the study was to examine the impact of secondary school geography content in mitigating climate change in Uganda.

\section{Objectives of the study}

The study sought to;

i. Establish the aspects of climate change taught in secondary schools in Uganda.

ii. Examine the teachers' perception on climate change content in secondary school geography curriculum in Uganda

iii. Assess the climate change content in secondary school geography learning resources in Uganda. 


\section{Methodology}

This study used a descriptive survey because it was deemed most appropriate in identification of people's opinions about a phenomenon (Mugenda and Mugenda, 2003). Questionnaires and interviews were used to collect data. Eighty seven Secondary school geography teachers (71 answered questionnaireand 16 interviews) participated in the study. The participants were drawn from private, community and public secondary schools in four districts of Karamoja (North Eastern region), Bududa (Eastern region), Kayunga (Central region) and Kasese (Western region). The selected district have experienced extreme climate change events including unprecedented flooding, drought, landslides and the disastrous effects namely death of animals, crop failure, food insecurity and hunger, loss of human life among others. Simple random sampling and purposive sampling was used to select respondents in the study. A documentary analysis of the O- level geography syllabus was also conducted.

\section{Findings}

Data collected revealed that the aspects of climate change taught by geography teachers at "O" level include causes of climate change (73\%), effects of climate change (65\%), adaptation strategies $(28 \%)$ and vegetation (65\%). Vegetation is not a direct aspect of climate change but it gives an opportunity to teach about climate change. A respondent observed that "causes are the trigger and any effort to mitigate climate change should start by making the students aware of the driving factors of climate change".

Another respondent remarked that "it is important for learners to understand the genesis and supporting factors of society's problems in order to be able to find appropriate solutions to the problems". Arespondent observed that it was important for learners to know the effects of climate change noting that one student had inquired during a lesson "why there were no mangos in August and September yet all along August and September was a mango season". This implies that the students and teachers observed climatic changes and its effects but could neither understand the causes of the changes nor link them to climate change.Teachers however disclosed that they had challenges choosing aspects of climate change to teach in classrooms because they were not well acquainted with it, it is rather scientific, it does not appear in the curriculum and it is not examinable.Majority of the respondents $(78 \%)$ held the view that the recommended learning resources by National Curriculum Development Center (NCDC) i.e. the syllabus, textbooks, reference materials are old version published between the 1956 and 2005 and do not provide adequate content on climate change. Table: 1 presents a list of approved reference:

Table 1: List of reference books in the O level Syllabus

\begin{tabular}{|c|c|c|c|}
\hline Author & Title of the book & Year & City/Publisher \\
\hline Bunnet R., B. & Physical geography in Diagrams for East Africa & 1984 & Hong Kong, Longman \\
\hline Gibbs C. W. & The Rhinelands & 1987 & $\begin{array}{l}\text { Nairobi: East African Publishing } \\
\text { House }\end{array}$ \\
\hline NCDC, Uganda & Potentials, prospects and Problems in World development & 1989 & London: Basingstock: Macmillan \\
\hline Gladys, Hickman & Lands and Peoples of East Africa & 1986 & Hong Kong: Longman \\
\hline $\begin{array}{l}\text { Hickman, G.M (et } \\
\text { al) }\end{array}$ & Lands and Peoples of East Africa & 1973 & Singapore: Longman \\
\hline Hughes D. Randle & The Rhine Basin, A study of Development & 1979 & Hong Kong: Longman \\
\hline $\begin{array}{l}\text { Karuggah, R. } \\
\text { \&Kibuuka, P. }\end{array}$ & Certificate Geography, Form I & 2003 & Nairobi: Oxford University Press \\
\hline $\begin{array}{l}\text { Karuggah, R. } \\
\text { \&Kabuusu, J. }\end{array}$ & Certificate Geography, Form II & 1993 & Nairobi: Oxford University Press \\
\hline $\begin{array}{l}\text { Karuggah, } \mathbf{R} \text {. } \\
\text { \&Kabuusu, J. }\end{array}$ & Certificate Geography, Form III & 1993 & Nairobi: Oxford University Press \\
\hline $\begin{array}{l}\text { Leong G.C. \& } \\
\text { Morgan G.C }\end{array}$ & Human and Economic Geography & 1973 & New York: Oxford University Press \\
\hline Micheal Senior & Tropical Lands & 1979 & Hong Kong: Longman \\
\hline Minns, W. J. & A geography of Africa & 1984 & Hong Kong: Macmillan \\
\hline NCDC, Uganda & Uganda, Secondary School Atlas & 1991 & Kampala: Macmillan \\
\hline NCDC, Uganda & $\begin{array}{l}\text { Integrates Geography: Environments, Population and } \\
\text { Development }\end{array}$ & 1993 & $\begin{array}{l}\text { Kampala: The Mac Millan Press } \\
\text { Limited }\end{array}$ \\
\hline Phillips, E.A.E.P. & Atlas & 1991 & $\begin{array}{l}\text { Nairobi: East African Education } \\
\text { Publisher }\end{array}$ \\
\hline $\begin{array}{l}\text { Senior, M } \\
\text { \&Wagula, F. N. }\end{array}$ & $\begin{array}{l}\text { A complete Senior Course in Human and Economic } \\
\text { Geography }\end{array}$ & 1992 & Nairobi: Longman \\
\hline Swayne, J.C. & A concise Glossary of Geographical Terms & 1956 & London: George Phillips and Sons. \\
\hline UNEB & $\begin{array}{l}\text { Uganda Certificate of Education, Regulations and } \\
\text { Syllabuses 2006-2010 }\end{array}$ & 2005 & Kampala, UNEB \\
\hline White, R.G. & Africa: Studies for East African Students. & 1982 & \\
\hline YigaMatovu M. & North America, Certificate Geography, & 1984 & Nairobi: Oxford University Press \\
\hline Young \& Lowry & $\begin{array}{l}\text { A course in World Geography: East Africa, Physical, } \\
\text { Regional and Human }\end{array}$ & 1977 & India: Edward Arnold \\
\hline \multicolumn{4}{|c|}{ ource; "O level geography syllabus, NCDC (2008). } \\
\hline
\end{tabular}


A teacher commented about the recommended textbooks;

We are teaching static geography. The current issues are not covered by the recommended textbooks and reference materials and it is quite hard to make meaning and connections of current issues like climate change to students". Another teacher revealed that the curriculum has a topic on climate but does not mention "anything on climate change". The teachers take the curriculum as an absolute document that has to be followed religiously.Data revealed that school textbooks were not readily available in schools. A teacher in a private school noted that the school does not have textbooks and this sentiment was reflected in other schools:

"I have never seen a single textbook of geography in this school. The books are expensive and therefore finance resources cannot allow. They gave me a job and they expect me to know what to teach. It is a complicated situation".

Another respondent remarked:

"Textbooks! No way. I don't have them... Where do I get that money to buy them? If schools cannot afford them what about me a mere teacher!!! I teach in three schools but none has a geography syllabus. It is not easy to have text books... they are expensive".

A respondent hinted that the available text books were out of dated and of less use:

The available geography textbooks have outlived their time, they are outdated. I feel that they are not important anymore... something has to be done otherwise we are practicing our profession in the shadows.

A respondent remarked that it is upon teachers to devise means of getting textbooks because schools don't provide them. The teacher noted that:

I have two geography textbooks which my father bought for me when I joined National Teachers College ten years ago. Schools don't have text books, they don't have money to buy text books because they are expensive, if you really want to be perfect at your job, you have to improvise and buy some books from your salary.

Some respondents observed that climate change implicitly appears in the O level geography curriculum. One respondent observed that most topics appearing in the curriculum cannot be taught without talking about climate change.

When I am talking about the various topics like climate and weather, climate of East Africa, industrialization, drought, regional geography, climate variability, map work and photographic interpretation, I bring out climate change issues because they are embedded within there.

This revelation implies that a variety of topics in the curriculum have inner climate change content or at least opportunities exist for teaching climate change. The respondent observed that he only has to "skillfully" make linkages of the topics to climate change so that the students see the implication of climate change on the various aspects of the environment, economic activities and political policy. One teacher observed that:

The challenge is that teachers are stuck in the past. They are teaching what they learnt at school at the same level using yellow notes given to them by their teachers as if it is a Bible. They are not doing personal reading, not getting any refresher training and NCDC is silent.

Another respondent remarked that:

I teach using pamphlets which are in question and answer form. The pamphlets have revision questions or examination past papers and surely they are deficient in content on climate change.

Most of the schools that participated in this study did not have the geography teaching syllabus of 2008, which forms the basis for teaching geography at O level. Most of the geography teachers continued to teach using the examination syllabus 2006-2010 which was phased out when the harmonized geography education syllabus was launched in 2008. It is undisputed that teachers are reluctantly retrieving climate change information for the benefit of their students.An analysis of the $\mathrm{O}$ level secondary school geography syllabus revealed that environment management is clearly included but climate change management and mitigation does not openly appear. However, climate change issues are appearing in the background of various topics across all the levels of the curriculum as indicated in Table. 2.

Table: 2: Climate change and related content in O level secondary school geography syllabus

\begin{tabular}{|c|c|}
\hline Class & Content areas for covering climate change \\
\hline Form I & $\begin{array}{l}\text { Aspects of the environment, weather and climate, factors affecting major climates of the world, North America- types of } \\
\text { climate and factors affecting them, types and factors influencing vegetation of North America, the utilization of natural } \\
\text { resources in British Colombia, importance of forestry to other resources, factors favoring forestry, problems facing forestry } \\
\text { and ways of improving forest industry, ways of improving forestry activities, utilization of water, problems facing fishing } \\
\text { industry, hydroelectric power generation, mining, growth and development of New York as a city port, effects of urbanization, } \\
\text { industrial development, location and physical conditions of cotton belt- factors that led to decline in cotton growing in old } \\
\text { cotton belt, new trends in agricultural section, problem, contributions and solutions of the industrial sector to the south. }\end{array}$ \\
\hline Form II & $\begin{array}{l}\text { The St. Lawrence sea way project- negative effects of the sea way (pollution from industries, flooding), industrial development } \\
\text { in New England- problems resulting from industrial growth and development, development of semi-arid environment (South } \\
\text { California - physical and human factors facilitating and problems facing fruit farming in central valley, physical features of } \\
\text { East Africa- processes for the formation of main relief features of East Africa, the soils of East Africa (weathering and soil } \\
\text { formation, mass wasting, soil erosion, conservation/management of soil. The climate of East Africa-factors influencing rainfall }\end{array}$ \\
\hline
\end{tabular}


factors favoring forestry, problems facing forestry, population of East Africa - effects of population distribution in East Africa, development of agriculture in East Africa, mining in East Africa, Industrial development in East Africa (problems created by the development of industries)

Form Fishing in East Africa- problems facing fishing industry in East Africa, wild life conservation and tourism in East Africa, III contributions and challenges to tourism industry, problems of urbanization of East Africa, problems of urbanization of East Africa, challenges affecting trade in East Africa, map work-relationship between relief and other aspects (physical and human), photographic interpretation, fieldwork, physical characteristics of Switzerland, contribution and challenges of agriculture, industrial development, contribution and challenges of tourism industry, contribution and challenges facing agriculture, industrial development and urbanization in Rhine Rift Valley, Germany, Netherlands, Belgium, population distribution in Luxemburg, challenges of Rhine water way, challenges facing Rotterdam as an international Port.

Form Relief and land features in Africa; processes of the land formation of relief and land form features, agencies that modify relief IV and land from features and their influence on human activities, characteristics and factors affecting climate in Africa, characteristics and factors affecting vegetation in Africa, population distribution, growth, characteristics and problems in Africa. Contribution and challenges of agricultural practices in Africa, contribution and challenges of multi-purpose schemes and river development in Africa: e.g. Kariba, Volta Aswan, use and development of forest resources in Africa, development of mining industry in Africa, contribution of industrial development in Africa, contribution and challenges of the fishing industry, urbanization and trade in Africa.

Data revealed that the teachers' source of information on climate change include the internet $(66.2 \%)$, Radio (43.7\%), Television (35.2\%), Newspapers (42.3\%) journal articles (23.9\%), geography textbooks and books/publications $(47.9 \%)$, meteorological information services $(11.3 \%)$, community conversations $(5.6 \%)$, personal observations and experiences (8.5\%). Other sources include agricultural extension services, environment education and awareness programmes and campaigns (11.3\%). However rural schools lacked access to Televisions, newspapers, computers and internet connectivity; and skills to use the internet.

Various information sources provide information that is dissected and sometimes contradicting each other. Arespondent remarked:

Most of the information available at the community level is not edited and it is from untrusted sources. Many times the information is either mixed up or out rightly wrong. For example the leaflets claimed that landslides on the slopes of Mt. Elgon are caused by settlement and cutting trees on the slope which is not entirely true, the vegetation is thick and the area receives heavy rainfall which pushes the boulders down slope. It is unreliable information.

Limited resource centers to provide trusted information on climate change came out among the problems. A respondent remarked through interview that;

There are no community libraries in our locales where we would access information about climate change at no cost. At my school, we don't have a library but a book store and available books don't have literature about climate change. Most of the books available are donated by foreign friends and they are outdated. It is more of dumping than donating. The available sources of information are internet cafes that are distant and the user fees are not affordable for teachers.

Respondents stated that $\mathrm{O}$ level geography education develops among students skills of mitigating climate change i.e. environmental conservation skills, interpretation skills, Field work skills and analysis skills which are useful in lessening climate change. A teacher revealed that "content for various topics for example agriculture develops skills in land management, i.e. tree planting, mulching, shifting cultivation, agro forestry that are vital in environmental conservation and climate change mitigation".

Geography education also promotes values of social justice, personal and social competence and Empathy. A respondent noted that "when students have empathy for the environment they value it and strive to protect it so that they maximally benefit from it". Another respondent disclosed that "the values of social justice as well as personal and social competence include students knowing the importance of planting trees, using better farming methods like intercropping, terracing, adopting organic farming and non-use of chemical laden fertilizers". The implication is that learners can preserve, protect and preserve their environment. One respondent urged that "with a sense of social justice, the students learn and seek ways of solving problems facing their environment through embracing and or developing innovations that minimize risks that deplete the environment which is one of the leading causes of climate change".

\section{Discussion}

The study reveals that the $\mathrm{O}$ level geography curriculum is deficient in content on climate change. This finding is related to findings of Ocheing \& Koske (2013); Togo, Zhou \& Khan (2015); Dlamini\&Shongwe, (2015); Chineka \& Chabikwa(2015); Alberto (2015); Ndiritu et al (2016); Monjane et al (2015); Bajracharya et al(2012) where curriculum of various countries i.e. Kenya, Nepal, Seychelles, Zimbabwe, DRC, Swaziland lacked content on climate change.

Geography teachers are taking the initiative to teach various aspects of climate change based on the window provided by various topics in the curriculum i.e. on environment, weather and climate as observed by Dlamini \& Shongwe (2015); Chineka \& Chabikwa(2015). Aspects of climate change taught in secondary schools include the causes, effects and adaptation strategies. The teachers' action to teach about climate change 
seems to be driven by the teachers' realization that climate change is a serious issue worth teaching. This is in agreements with Eisner (1990) who advocated for teaching content which is "worth teaching". As a fact, climate change is one issue that is worth teaching not only for adaptation and mitigation of its effects but also to ensure behavioral and attitude change so as to avoid further deterioration of the situation. Because of the lack of explicit presence of climate change in the curriculum, teaching of climate change does not get the attention it deserves, because the topic is not examined. Such teaching where climate change is mentioned as add-on in environment related topics in geography classrooms may not be sufficient to bring out meaningful pro-climate change mitigation behavior among learners as observed by Bangay \& Bloom (2010).

The O level geography curriculum and textbooks do not provide adequate content on climate change. This confirms Kira \& Komba (2015) findings in Tanzania that geography textbooks were outdated and provided unclear concepts on issues of environmental degradation, weather and climate, power use and climate change. It is also similar to the situation in Seychelles where there are no specific resources to help geography teachers integrate climate change comprehensively in their lessons (Ndiritu et al, 2016). The recommended reference materials used in O level are old versions published way back in the 1960s to early 1990s when emerging issues like climate change were not of concern as it is today. UNESCO (2016) observed that textbooks in Sub Saharan Africa are outdated and for that matter unlikely to pave way to sustainable development through sustainable management of the environment. This finding is also in agreement with Kagoda (2009)'s observation that geography textbooks and reference materials are outdated. In the event that textbooks are the first and sometimes the only books that a young person may read (Lässig and Pohl, 2009) and the fact that in most classrooms textbooks determine what and how teachers teach (UNESCO, 2016), the teaching and learning of climate change in Uganda depends on the interest of individual teachers and students. Geography being a dynamic subject, the books being used in addition to the existing curriculum, teachers are teaching static geography, implying that geography education is not fulfilling its mandate.

The content of $\mathrm{O}$ level geography needs updating to integrate new trends in education so that geography education is fit for purpose. Kagoda (2009) discovered that some teacher training institutions and secondary schools lack up-to-date text books and inadequate instructional materials. This means that some of the teachers graduating from the teacher training institutions are coming out with un useful geography knowledge. It also implies that the students' school experiences may not adequately help them solve the community challenges and mitigating climate change as well as to meet the expectations of the education system.

The information on climate change at community level is contradicting and unreliable. UNESCO (2016) revealed that textbooks are increasingly focusing on environment but some (textbooks) refute scientific findings on climate change. The implication is that if geography textbooks are believed to be authoritative and trusted by students and teachers as UNESCO (2016) observes, then there is a high possibility that the information received by students and teachers is contradicting and confusing and therefore reinforce the learners' misconceptions. Therefore, the school experiences would have no consequence in countering climate change as was the case with American students (Choi et al., 2010). In this respect, the O level geography content is somehow failing on its mandate of producing future generations of environmental and climate scientists, much less the kinds of minds that will create new knowledge, innovations and inventions that are needed in mitigating climate change.

Geography textbooks were not available in schools. This is in agreement with the studies in Mbugua (2011); Orina (2001) in Kenya, Kira \& Komba (2015) in Tanzania and Bizimana \& Orodho (2014) in Rwanda. The availability of text books is dependent on how books are acquired. Schools lack resources to buy geography textbooks and the geography teachers look to friends from whom they borrow textbooks to read about some topics just as Mbugua (2011); Orina (2001) and Kira \& Komba (2015) found out the inadequacy of textbooks in schools and therefore teachers improvise to get textbooks. Teachers do all within their means to get textbooks in order to get reliable information on the various topics because they were approved by the relevant organs and add the fresh to the outline syllabus as Mbugua (2011) observed. Similarly Kira \& Komba(2015) observes that textbooks provide a direct source for students and stable knowledge for teachers when searching for basic knowledge and in accessing students' learning.

There is shortage of e-learning resources and equipment i.e. Television sets, video players, projectors, CD-rom, slides, tapes, films etc. This is related to Mathevula (2015) findings of the lack of ICT equipment in Limpopo South Africa that affected the teachers negatively. The absence of education technologies in school negates its benefits and affects teaching and learning especially catering for individual learners' differences and development of $21^{\text {st }}$ century skills through the multi-sensory tenet, which are critical in mitigation of climate change. In the observed lessons, teachers selected relevant films which had rich information and the learning experience of the learners was worthwhile. Some schools lack access to electricity while other schools lack internet connectivity. Fagbamiye (2015) observed that the cost of internet connectivity in Africa is high citing Uganda where internet services is said to be $150 \%$ higher than the same service cost in United States of 
America. In schools that had the computers, teachers exhibited lack of skills to use them while other exhibited lack of interest. This is congruent with Fagbamiye (2015) observation that teachers have not been trained to use the ICT and how to integrate them in their teaching-learning process.

The $\mathrm{O}$ level geography education enhance skills and values of environmental conservation. In developing the values of environment conservation, the students realize the importance of their environment, they understand its value, and they make meaning, connections and linkages of the environment and their wellbeing and become consciously aware of the need to preserve, protect and use it sustainably. The processes that education provides and the attained values help students develop competences and independent learning; in planning and decision making; in communicating with others and building useful meanings and mitigation on climate change as Meil (1956) observed. Meil (1956) adds on that content includes approaches to situations and materials that add value, initiative, creativity, and inventiveness, good feelings towards oneself and other people as well as their environment.

\section{Conclusion}

Climate change does not explicitly appearin the secondary school geography curriculum which is indeed a challenge to teachers. The content on climate change however appears in the background of different topics namely agriculture development, elements of weather, East Africa, fishing, forestry resources, development of tourism, industrialization, urbanization, population distribution in relation to resources and environment, vegetation, etc. It requires expertise of teachers to retrieve the climate change content from the background of the various topics and teach it. However the expertise of teachers in climate change is low. In the prevailing circumstances, it is upon the interest and knowledge capability of teachers about climate change to retrieve the content and teach it. Teachers place a high value on climate change as an issue their students should know although they are constrained by a variety of factors namely inadequate information and information sources about climate change, unedited information materials on climate change which is utmost contradicting, misconceptions from the media and more so climate change not being explicitly in the curriculum and not being examinable by UNEB.

Some teachers are teaching topics in isolation without making connections to other topics and real life situations namely the floods, droughts, food insecurity, declining pastures and disasters. This format of teaching is not helpful in geography as the nature of the subject has content which is overlapping and evolving that for maximum attainment of learning outcomes, content should be covered in a way that link it to real life situations. Besides, teachers believe that climate change is highly scientific, abstract and a complicated topic to teach. This explains why teachers have challenges on delineating the aspects of climate change to teach. It is clear that even as the curriculum designers gave teachers the right to supplement content, they assumed that the teachers were competent to do so which is not the case. Lastly, the NCDC and UNEB are detached from the teachers. There is no circular or guidelines on coverage of an emerging issue like climate change and Sustainable Development Goals (SDGs) yet this would give endorsement to teachers to embark on teaching such topics.

\section{Recommendations}

1. The NCDC should integrate climate change in the O level geography curriculum.

2. Teacher Training Institution should organise refresher training of teachers on emerging issues and serious society problems like climate change, population pressure, sustainable development goals, and food insecurity to furnish the teachers with relevant information and methods necessary for their professional practice.

3. The Ministry of Education and Sports should include Geography in the School Science and Mathematics Teachers project (SESMAT) because Geography has a high element of climate science and forms combinations of science subjects at A level. Improving understanding of climate change will help improve performance in science courses like meteorology, urban planning, agriculture, geology among others.

4. Head teachers should establish school networks to facilitate sharing of resources like textbooks, reference materials and other learning. At present networking is not present even at school level.

\section{Reference}

[1] Alberto, Z. N. (2015). Angola's Experiences with Climate change Education in School Curriculum. In Nhamo, G. \&Shava, S. (Eds.).Climate Change Education in SADC School Curriculum. Africa Institute of South Africa, Pretoria, p 285-289

[2] Bajracharya, R., Ale, B.B., Bhusal, C.L., Jnawali, D., Kafle, B.D., \&Sapkota, B. (2012) Nepal: Strengthening Capacity for Managing Climate Change and the Environment-Recommendations for Academic Curricula on Climate Change and Environmental Management. Government of Nepal, Ministry of Environment, Science and Technology, Kathmandu, Nepal

[3] Bangay, C. \& Blum, N. (2010). Education Responses to Climate Change and Quality: Two parts of the same agenda? International journal of Educational Development. 30(4): 335-450

[4] Bizimana, B. \&Orodho, J. A. (2014).Teaching and Learning Resource Availability and Teachers' Effective Classroom Management and Content Delivery in Secondary Schools in Huye District, Rwanda. Journal of Education and Practice, Vol.5, No.9, pp.111-122 
[5] Chang, C. (2013) Advancing a framework for climate change education in Singapore through Teacher Professional Development.HSSE online 2(1) 28-35.

[6] Chineka, R. \&Chabikwa, B. (2015). Curriculum Interventions of Climate Change mitigation and Adaptation: The Zimbabwean Experience. In Nhamo, G. \&Shava, S. (Eds.).Climate Change Education in SADC School Curriculum. Africa Institute of South Africa, Pretoria, p 261-282.

[7] Dlamini, S. B. \&Shongwe, M. (2015). Climate change education in Swaziland school curriculum.In Nhamo, G. \&Shava, S. (Eds.).Climate Change Education in SADC School Curriculum. Africa Institute of South Africa, Pretoria, p 200-220.

[8] Eisner, E. (1990). Who decides what schools teach? Phi Delta Kappan, 71(7), 523-526.

[9] Eisner, W.E.\&Vallance, E. (Eds.).(1974). Conflicting conceptions of curriculum. Berkeley: McCutchan.

[10] Fagbamiye, E.O. (2015). ICT and teacher education in East Africa. In Adegoke, B. and Oni, A. (Eds).Teacher Education Systems in Africa in the Digital Era, CODESRIA, Dakar, p.153-162

[11] Gosse, C. \& Hansel, L. (2014). Taken for granted: Why curriculum content is like oxygen? American Educator, Summer 19-43

[12] International Geographical Union [IGU].(2016).International Charter on Geographical Education.IGU Commission on Geographical Education, Amsterdam.

[13] Kagoda A.M. (2009).Teaching and learning geography through Small Group discussions. Current Research Journal of social sciences 1(2): 27-32.

[14] Kira, E.S. \&Komba, S.C. (2015). The Status of geography textbooks for teaching and learning of the concepts of meteorology and environmental education in Tanzanian secondary schools. International Journal of Education and Research Vol. 3 No. 9, pp.127140.

[15] Lambert, D. \&Morgan, J. (2010).Teaching Geography 11-18: A conceptual Approach. Open University Press, First Edition McGraw-Hill Education Berkshire, UK

[16] Lässig, S. \& Pohl, K. H. 2009.History Textbooks and Historical Scholarship in Germany. History Workshop Journal, Vol. 67, No. 1, pp. 125-39.

[17] Mathevula, M.D. (2015). The effects of Information and Communication Technology (ICT) on teaching and management of curriculum-related Activities: a case of secondary schools in the Groot Letaba Circuit, Mopani district in the Limpopo province. Unpublished Masters Thesis submitted to University of Limpompo

[18] Mbugua, Z. K. (2011) Adequacy and the extent to which teaching and learning resources for mathematics are available and used for achievement in the subject in secondary school in Kenya. America International Journal of contemporary Research, Vol. 1 No. 3 , pp.112-116

[19] Meil, A. (1956). Curriculum Content. Education Leadership, March pp.337 - 340 .

[20] Monjane,A., Mustafa, M. \&Tsambe,M. (2015). Climate Change Education in Mozambique.In Nhamo, G. \&Shava, S. (Eds.).Climate Change Education in SADC School Curriculum. Africa Institute of South Africa, Pretoria, p 300-306

[21] Muchanga, M. M. \&Nakazwe.M.K.(2015).Climate Change Education in the School Curricula of Zambia.InNhamo, G. \&Shava, S. (Eds.).Climate Change Education in SADC School Curriculum. Africa Institute of South Africa, Pretoria, p 241-260.

[22] Mugenda, O.M. \&Mugenda, A.G. (2003).Research methods: Quantitative and Qualitative Approaches. Acts Press, Nairobi

[23] Nancy, A. (2012).Climatic Change and Female Reproductive Health: The Case of Traditional Medicine in Tanzania. The Journal of Pan African Studies, vol.5, no.1, March 2012 pp. 23-35.

[24] National Association for the Education of Young Children [NAEYC].(1990). Guidelines for Appropriate Curriculum Content and Assessment in Programs Serving Children Ages 3 Through 8, NAEYC, Washington DC.

[25] National Curriculum Development Centre [NCDC]. (2008).273 Geography O-Level Syllabus, NCDC, Kampala.

[26] Ndiritu, K.C., Chweya, M.D., Mwangi, K.D. \&Glara, J.K. (2016).Infusing Climate Change Content into Kenya's Secondary School Taught Curriculum: Successes and Challenges.IOSR Journal of Environmental Science, Toxicology and Food Technology 1O(9), PP 23-29.DOI: 10.9790/2402-1009012329

[27] Ocheing, A. M. \&Koske, J. (2013). The level of climate change awareness and perception among primary school teachers in Kisumu Municipality, Kenya. International Journal of humanities and Social Science, Vol. 3 No.21 p.174-179.

[28] Ofsted (2008). Geography in schools: changing practice. Reference no.070044, London. Retrieved March, 12 , 2016 http://dera.ioe.ac.uk/8167/1/Geography\%20in\%20schools\%20changing\%20practice\%20\%28PDF\%20format\%29.pdf

[29] Orina, W.M. (2001). Availability, acquisition and utilization of instructional resources for teaching Geography in selected secondary schools in Central Kisii District, Kenya. Unpublished Master of Education Thesis, Kenyatta University.

[30] Rakib, M.A., Akter, M.S. and Majumder, K. (2016). Climatic Hazards and Social Crisis: A Quick Mitigation Approach to Accelerate Sustainable Development. Journal of Social Sciences 12 (1): 14.26 DOI: 10.3844/jssp.2016.14.26

[31] Skalik, J. (2015). Climate change Awareness and Attitudes of Adolescents in Czech Republic. Envigogika, 1-19 Doi: $10.14712 / 18023061.472$

[32] Stern, M.C \&Stern,J.A. (2011).The State of State U.S. History standards 2011. Thomas. B. Fordham Institute, Washington DC

[33] Taba, K., Mpolesha, D. \&Makaya, B. (2015).Climate Change Education in the Democratic Republic of Congo.InNhamo, G. \&Shava, S. (Eds.).Climate Change Education in SADC School Curriculum. Africa Institute of South Africa, Pretoria, p $290-299$.

[34] United Nations Educational Scientific and Cultural Organization [UNESCO].(2012). Climate Change Education for Sustainable Development. Paris: UNESCO.

[35] UNESCO (2016).Global Education Monitoring Report 2016. Education for people and planet: Creating sustainable futures for all. UNESCO, Paris, France

Mwangu Alex Ronald. "Impact Of secondary School Geography Education Content In Mitigating Climate Change In Uganda." IOSR Journal of Environmental Science, Toxicology and Food Technology (IOSRJESTFT) 11.7 (2017): 35-43. 